\title{
Wegener's Disease in a Black Malian
}

Dr. Sanogo A ${ }^{1-4^{*}}$, Diaby $\mathrm{Lm}^{2-4}$, Diallo L ${ }^{4}$, Maiga ${ }^{3-4}$, Kane $\mathrm{AST}^{1},{ }^{3}$, Camara $\mathrm{Y}^{6}$, Sow $\mathrm{S}^{2}$, Diakite $\mathrm{Y}^{3}$, Kaya Assetou Soukho ${ }^{5}$

${ }^{1}$ Infirmary of the Internal Medicine Service of BAMAKO hospital

${ }^{2}$ Infirmary of the Internal Medicine services of Kati hospital

${ }^{3}$ Hospital of Sikasso Mali

${ }^{4}$ D.C.S.S.A Mali

${ }^{5}$ Internal Medicine Service CHU Point G Bamako

${ }^{6}$ Central Military Hospital Niger

DOI: $10.36347 /$ sjmcr.2021.v09i01.004

| Received: 13.12.2020 | Accepted: 24.12.2020 | Published: 09.01.2021

*Corresponding author: Dr. Abasse Sanogo

Abstract

Review Article

Wegener's disease is a very rare condition in Africa. In 1931, a German student, Heinz Klinger, reported an unusual observation of peri-arteritis, this was characterized by pneumo-renal syndrome, severe airway involvement including rhinitis, nasal saddle, pan-sinusitis, middle ear, laryngo-tracheal and bronchial ulcerations and oneExophtamos. Autopsy examination revealed the presence of necrotizing and granulomatous vasculitis in the upper and lower airways, associed with increasing glomerulonephritis[1]. The objective of study is to show the existence of Wegener's cases in our county, Observation: this is a 28-year-old patient followed by ENT for nasal-sinus polyposis, hospitalized for chronic cough with sputummuco-purulent sometimes streaked with blood with deterioration of the general condition; pathological examination of the biopsy nasal specimen concluded with the diagnosis of Wegener's granulomatosis. Discussion: GW can be seen at all ages the average age at diagnosis is between 40 and $50 y e a r s$, with a slight male predominance in some series (table 23-11), which does not appear to be significant in the studies epidemiological[6]. Less than $15 \%$ of cases are pediatric. The presence of high titer ANCA with antiproteinase 3 specificity is a strong argument for the diagnosis of GW; on the other hand, the negativity of ANCAs should not make the diagnosis rejected, in particular in the face of a form of limited appearance. Histology remains a powerful and often essential diagnostic element, because, as often in systemic granulomatosis, the diagnosis can be discussed at the bordes of infections caused by intracellular bacteria and lymphoproliferative syndromes (in particular lymphoid granulomatosis of liebow) [80].

Keywords: Wegener, granulomatosis; black; Malian.

Copyright $(\odot 2021$ The Author(s): This is an open-access article distributed under the terms of the Creative Commons Attribution 4.0 International License (CC BY-NC 4.0) which permits unrestricted use, distribution, and reproduction in any medium for non-commercial use provided the original author and source are credited.

\section{INTRODUCTION}

Wegener's disease is anextremely rare condition in Africa. In 1931, a German student, Heinz Klinger, reported an uncommon case of Polyarteritisnodosa. It was characterized by a pneumo renal syndrome, a severe impairment of the airwayswith rhinitis, saddle nose, pan sinusitis, otitis media, laryngotracheo bronchitis and exophthalmos. Autopsy examination revealed the presence of necrotizing and granulomatous vasculitis of upper and lower airways, associated with ascending glomerulo nephritis [1]. It was in 1936 and 1939 that Friedrich Wegener, affected by the precocity and intensity of the damage to upper airways, described three cases of the disease which bears his name [2]. The main anatomical features of Wegener granulomatosis $(\mathrm{GW})$ were documented in a study of 7 cases by Godman and Churg [3] in 1954, which emphasized the rapidly fatal nature of the disease. Carrington and Liebow [4] proposed in 1966 the concept of limited form of GW, characterized by predominant pulmonary involvement, the absence of renal damage and a better prognosis compared to the classical diffuse form: with a decline of 4 to 150 months, half of their patients were alive. By 1973, Fauci et al. [5] suggested the efficiency of the combination of corticosteroids and oral cyclophosphamide, which allowed remission in 93\% of the cases. A renewed interest for this disease came from the demonstration of specific autoantibodies against a constituent of the cytoplasm of neutrophils (ANCA Anglo-Saxon authors). ANCAs have emerged as a new diagnostic tool and an etiopathogenic component of systemic vasculitis in the broad sense and GW in particular.

Epidemiological data come only from AngloSaxon sources. In the United States, the prevalence of $\mathrm{GW}$, estimated from hospital registers, is 3 per 100000 population [6]. Geographically, it decreases according 
to decreasing gradient from West to East. In Great Britain, the analysis of hospital records by British Thoracic Society permitted to identify 265 cases of GW diagnosed between 1975 to 1985 [7 ]. A population survey identified 17 new cases between 1985 to 1989 in Leicester, corresponding to a five -year impact of 1.3 per 100,000 populations [8], and a prevalence of 2 per 100,000 populations. Between 1988 and 1994, the impact of GW in the Nordwich was 8.5 per 1 million population [9], a significant increase compared to the previous period. The increase of the impact may be real [9] or may simply be the reflection of a difference in methodology or an improvement of the diagnosis. The onset of the disease would be seasonal, with maximum frequency in spring and winter, minimal frequency in autumn and especially in summer [9-11]. On the other hand, the total number of hospitalization, which mainly includes symptomatic bout, whether or not they are inaugural, does not seem to have changed according to seasons [6]. In USA, a national computerized register identified 1,784 deaths due to a GW between 1979 to 1988 [6], of which $1.23 \%$ of the death were recorded in children under 15 years. The mortality rate averaged 0.8 per million population. This number increased from 0.6 in 1978 to 1 per million in 1990. There was excess male mortality and among Caucasians, noting that the Caucasian population is the main target (more than 80 per cent) of the disease. Prevalence and age at death were similar for both men and women.

GW histologically associates 3 main lesions: giant cell granuloma, necrosis and vacuities. These 3 elements, analyzed in isolation; are encountered in 20 to $30 \%$ of the upper airways biopsy however, the complete triad is observed in only 3 to 16 percent of the cases [12]. The diagnostic usefulness of the biopsy depends mainly on the size of the swab, which is the maximum for open-chest biopsy. Heterogeneity in the distribution of lesions, noted over serial sections within a single biopsy, appears in itself a diagnostic guide. The cellular inflammatory infiltrate is a polymorphic granuloma that typically has a palissadichistiocytic infiltrate and many multinu key giant cells. The presence of neutrophils or eosinophils and plasma cells is less specific. The granuloma may be intra-, peri- or extravascularly situation. It is sometimes centered on non-caseous necrosis. Necrotizing vasculitis is acute, circumferential; it concerns arterioles and small veinlets. It may appear isolated, without granuloma or tissue necrosis. Capillarity is possible, mainly involved in necrotizing glomerulonephritis and intra-alveolar hemorrhage. Thrombosis of large arteries, responsible of ischemic necrosis seems underestimated as it has a significant role in the case of $\mathrm{CO}$ fail fatal multiorganance $[13,14]$. Necrosis can adopt extravascular tissue topography, without coexisting with a phenomenon of vasculitis. Moreover, the presence of micro Polynuclear abscess is quite common and especially precocious, constituting a good presumptive argument in cases of incomplete histological evidence.Lesions predominate in the upper airways, lung and kidney. The respective distribution of vasculitis and granuloma varies according to organs: at autopsy, a granuloma is present in the lung in $81 \%$ of the cases, in the kidney in $66 \%$ of the cases, in the spleen in $55 \%$ of the cases, in the upper airways in $51 \%$ of the cases and in the heart in $11 \%$ of the cases. Vasculitis lesions predominate in the lung (87\%), kidney and spleen (77\%), and are present in the upper airways only $25 \%$ of the cases [14].

The accountability of an infectious agent colonizing the upper airways has been raised since the first descriptions [15] but no evidence of causal infection has been found so far, including the study of the washing liquidbronchoalveolar [15]. However, a starting role is likely:

- a viral or bacterial infection would precede a push in $45 \%$ of renal relapse cases [15];

- a seasonal predominance (spring, winter) of the inaugural thrust has been noted in some series [11];

- chronic nasal portage of staphylococcus coagulase positive is associated with a significantly higher frequency of relapses [17];

- $\quad$ an antibiotic, cotrimoxazole, appears to be effective in the treatment of certain limited forms of GW [18 ] and in the prevention of relapse [19]. Chronic parvovirus B19 infection, suspected to be associated with GW [20, 21], was "cleared" by the constant negativity of viral nucleic material research in 42 adults with Wegener disease of recent appearance [22]. The existence of a genetic predisposition remains controversial: a significant association, in small rule, was found, in a variable way according to the authors, the studied ethnic groups and the techniques used, as well with the HLA antigens of class 1: HLA-B7, B8 [23], B50 [24], than Class 2 [25]: DR1 [26], DR2 [23] and DR9 [28]. Family forms are also exceptional [2931]. Autoantibodies against cytoplasm of neutrophils and monocytes (antineutrophilcytoplasmicantibodies, ANCA) have acquired their status as a marker of $\mathrm{GW}[32,33]$. ANCAs are not just a diagnostic test or scalability of vasculitis. They are also a conceptual and nosological tool: $\mathrm{GW}$ is now an autoimmune disease [34]. The presence of ANCA in the serum of patients with necrotizing glomerulonephritis was initially observed in 1982, but the link with Wegener's disease was only formally established in 1985 [35, 36]. The antigenic targets of ANCAs are mainly enzymes contained in the cytoplasmic granules of neutrophils.

The aim of this study is to show the existence of Wegener cases in our county. 


\section{ObServation}

I mean a 28 year old patient followed ENT for nasal polyposis -sinusienne hospitalized for chronic cough with muco-purulent sputum sometimes streaked with blood and a poor general condition. Her temperature was $40 \mathrm{C}$ with oscillation. On the ENT examination there was ulceration of the cornet with pus at the left sinus punctiform; parotid bilateral inflammatory hypertrophy.

The pleuropulmonary examination had found diffuse bilateral crackles. Dermatologically, papular macules was noted on the thorax and on the face. Elsewhere there was diffuse bilateral and peripheral joint pain.

We had found the paraclinical examination: Biology showed leukocytosis 262,100 cells / mm3 and anemia to $6.7 \mathrm{~g} / 1$; an absence of proteinuria to the test strips. The dosage of c-ANCA by IF1- inova- IL was positive at $28 \mathrm{IU} / \mathrm{L}$.

The radiograph of the frontal thorax showed multiple bilateral macromolecular images, diffuse, excavated peripheral.Sinus CT showed osteolysis and chondrolysis of the nose.

Pathological examination of nasal biopsy at a Wegener granulomatosis. We used concomitant prednisolone at a dose of $1.5 \mathrm{mg} / \mathrm{kg} /$ day and methotrexate at a weekly dose of $25 \mathrm{mg} /$ week for injection plus $15 \mathrm{mg}$ folic acid per week.

There was a clear improvement of the disease during the first two (weeks) of the hospitalization.After release of the patient, she had a pulmonary complication that led to the emergency and the death was found on arrival.

\section{DISCUSSION}

GW can be observed at all stages of life. Average age during diagnosis is between 40 to 50 years, with a slight male predominance in some series (Table 23-11), which does not appear to be significant in epidemiological studies [6]. Less than $15 \%$ of the cases are pediatric [37]. The delay of average diagnostic is one year. This delay is in fact extremely variable, significantly longer in forms without renal involvement $[4,38]$ where the evolution is often insidious, interspersed with spontaneous remissions of several months or years. In the study of NIH (National Institutes of Health, Bethesda, USA), the diagnosis was delayed by 5 to 16 years in $8 \%$ of the cases [39]. The onset is generally marked by nasal or respiratory symptoms of commonplace, including recurrent evolution, resistance to antibiotic treatment but sensitive to short corticosteroid therapy, association with fever, progressive deterioration of general condition or visceral involvement should receive attention. Elsewhere, the evolution can be done in an acute mode with the installation in a few weeks of a diffuse attack from the outset, both ENT, pulmonary and renal.

The radiological aspect is of a great diversity. The CT scan of the chest is essential, to highlight non visible lesions on X-rays and to clarify their appearance. Typically, it is about nodular opacities, of variable size (from a few $\mathrm{mm}$ to several centimeters), of sometimes pseudo-tumoral aspect, most often multiple, bilateral, well limited, without particular topographic distribution and evolving towards the excavation in half of the cases. Infiltrates are also common and can be distinguished into 3 types [40]:

- diffuse alveolar opacities, bilateral, sparse and asymmetrical, which lead to intra-alveolar haemorrhage

- Opacity low density but localized, variable from one cliche to another and finally

- Dense opacities, localized and able to develop towards the excavation.

The spontaneous disappearance of parenchymal lesions is possible, but rarely is it durable [4, 41]. In some cases, radiological abnormalities remain stable for months or even years without evidence of systemic spread of the disease [41].The simple excision of nodules can exceptionally remove the pulmonary symptomatology and general signs in the absence of anti-inflammatory treatment in a limited form [41] but such an evolution cannot be expected. A diffuse interstitial infiltrate is exceptional and must seek a diagnostic alternative. Treatment progress is usually towards the rapid disappearance of lesions, sometimes at the cost of scarring emphysema where aspergilloma may be grafted [42], or rarely calcification [40, 5]. Intravenous haemorrhagealveolar, responsible for acute respiratory failure sometimes fatal, affects 5 to $13 \%$ of the patients with a lethality of the order of 50\%.100 [40, $43,44,45,46]$, The possibility of pneumorenal syndrome with concomitant presence of glomerular basal antimembrane antibody and ANCA has been reported [47].

Bronchial stenosis is the same mechanism as subglottic stenosis.

\section{Mucocutaneous damage}

Mucocutaneous involvement affects about half of the patients $[48,49,50,51,52,53]$. It is present initially in 4 to $73 \%$ of the cases according to the series.Very polymorphic, more common in diffuse forms $[49,50]$, it is dominated by infiltrated purpura, papules, subcutaneous nodules, pustules and hyperplastic gingivitis. Macular or maculopapular rash [5 4], genital ulceration, gangrene of the extremities are more rare.Cutaneous ulcers may cause a pyodermagangrenosum [55]. Other manifestations are anecdotally reported: painful induration of the 
postoperative scar, palpebral xanthoma accompanying a pseudotumor of the ipsilateral orbit $[50,56]$, erythema elevatumdiutinum [57].

Histological examination, easy to perform, reveals lesions of non-granulomatous vasculitis in more than three quarters of the cases. Granulomatous extravascular lesions occur only in $5 \%$ of the cases. A palissadicgranuloma, centered by extravascular necrosis occurs in $10 \%$ of the cases [48-51]. The presence of granulomatous vasculitis seems rare. The immune fluorescence study may highlight deposits of $\operatorname{IgG}, \operatorname{IgA}$ or IgM, C3, of fibrin on dermal vessels [49-51] or may be negative [49]. Purpura lesions are never granulomatous and correspond to a non-specific leukocytoclastic vasculitis; their biopsy is thus of poor diagnostic efficiency and we will rather seek to take a nodular lesion $[48,50]$.

\section{Joint and muscular damage}

Arthralgia, or less commonly arthritis, occurs in 60 to 76 per cent of the cases, [3, 59], it occurs initially in half of these cases. The damage is polyarticular and symmetrical in two thirds of the cases, more rarely monoarticular. The wrists, knees and ankles are the joints most commonly affected. If an arthritis symmetrically affects the extremities and if is accompanied by rheumatoid factor, it may lead to anearly case of rheumatoid arthritis. However, the development is neither deforming nor destructive, although discrete erosive arthritis has been described [58, 59]. Synovial biopsy may reveal granulomatous synovitis. Myalgia is frequent, rarely reported to granulomatous acute myositis [60]. It may suggest Horton's disease or rhizomelic pseudo-rheumatoid arthritis, especially as temporal arteritis is possible [61, 62]. The diagnosis is then rectified by a secondary appearance of the damage of the airways.

\section{Biology}

Neutrophil leukocytosis, inflammatory anemia, thrombocytosis and elevation of inflammation proteins are the rule in diffuse forms. A leukopenia is exceptional [63] and must call into question the diagnosis. Eosinophilia occurs in $10 \%$ of the cases [13, $54,67]$. It is generally moderate, between 500 and 800 / $\mathrm{mm} 3$, higher numbers being nevertheless possible [54]. A form with predominant tissue eosinophilia, but without blood eosinophilia or asthma, has been described [65]. It is thought to be a borderline form with Churg and Strauss syndrome, especially since familial or personal allergic terrain (85 p. 100) would be more common in patients with GW [66]. Serum rheumatoid activity is detected in approximately half of the cases, rarely associated with the presence of cryoglobulin. There is usually no Hypergammaglobulinemia polyclonal. The serum complement and its actions are not lowered [5]. Search for antinuclear factors [5, 54, 64] and antigenemia HBs $[5,64,67]$ is negative. Hypercalcemia by secretion of a vitamin $\mathrm{D}$ metabolite or by association with hyperparathyroidism has been described. The cytokine dosing has been studied in short series. An increase in the level of interleukins 2 and interferon alpha [68] occurred. The serum level of the soluble receptor for interleukin-2 would be correlated with the progression of the disease, the increase of which could lead to a clinical relapse [6 9]. A rise in plasma level of thrombomodulin in the active phase of the disease is evidence of the extension of vascular lesions [71]. The increase in serum neopterin, secreted by macrophages under the influence of gamma interferon, seems correlated with the activity of the disease and the presence of infectious complications [72], the search for ANCA (see Pathogenesis and Diagnosis) is first performed by immune fluorescence screening. The ELISA technique subsequently makes it possible to type the antigenic reactivity of the positive sera and to titrate antiproteinase 3 antibodies.

Histological evidence of GW may be difficult to obtain because biopsies rarely associate the characteristic triad, which may warrant multiple and sometimes surgical specimens. As a result of these difficulties, the ACR proposed classification criteria to support the diagnosis of GW with $88.2 \%$ sensitivity to demonstrated vasculitis and a specificity of $92 \%$ [73]. The Chapel Hill consensus conference emphasized the histological aspect, defining GW by the presence of granulomatous inflammation of the airways and necrotizing vasculitis of vessels of small and medium caliber [74]. In fact, these classifications offer little diagnostic value at the individual level, but they make it possible to analyze relatively homogeneous groups of patients in clinical studies [75]. The detection of ANCA uses indirect immunofluorescence, the value of which depends very much on the experience of the operator. In practice, solid phase methods that use purified antigens are the indispensable complement of the immunofluorescence screening technique; they make it possible to determine the specificity and to quantify the ANCAs [76]. antiproteinase c-ANCA 3 have $90 \%$ sensitivity in generalized and active Wegener's disease, which decreases to $60 \%$ when the disease is localized; overall it is 66\% [75 ], c-ANCAs meet with great specificity, of $98 \%$, in a spectrum mainly covering $\mathrm{GW}$ but also micro polyangeite and some glomerulonephritic croissants. They are virtually absent in "classic" polyarteritisnodosa. The positive predictive value of c-ANCAs, ie in practice their diagnostic power, depends on the prevalence of $\mathrm{GW}$ in the targeted population; so when this prevalence is $5 \%$ in the patient population in a given service, the theoretical positive predictive value of c- ANCA is only 63\% [77 ]. A significant, as a rule, weak title of c-ANCA has been found in some patients with various conditions: uveitis, AIDS, hepatitis C, mycobacteriosis, aspergillosis, cystic fibrosis, infectious endocarditis, non-Hodgkin's lymphoma, rheumatoid arthritis. In these "entire false positive" cases, the search for antiproteinase 3 
Sanogo A et al., Sch J Med Case Rep, Jan, 2021; 9(1): 9-18

antibodies was negative, or unrealized. In contrast, the majority of sera tested in patients with hepatic amoebiasis appear to be associated with specific ANCA activity of proteinase 3 [78]. The p-ANCA are less specific and can be observed in some systemic vasculitis, such as allergic vasculitis, Churg-Strauss, in glomerulonephritis croissant, rheumatoid arthritis, induced lupus, polychondritisatrophic or inflammatory colitis, or even in healthy subjects [32, 79]. The differential diagnosis between GW and PCA, sometimes difficult, is discussed in the Polychondritechapteratrophic (637). In practice, in front of a suspect patient of GW, one must be able to identify subclinical ENT, pulmonary, neurological or renal impairment by proposing:

- A sinus scan and an ENT examination;

- A thoracic scanner of high resolution in thin sections;

- A possibly electromyogram;

- Repeated analysis of urinary sediment and proteinuria

The presence of high ANCA with a specificity of antiproteinase 3 is a strong argument for GW diagnosis; on the other hand, the negativity of the ANCA does not have to reject the diagnosis, especially in a "limited" appearance. Histology remains a powerful and often essential diagnostic element because, as often in granulomatosis systemic, the diagnosis may be discussed in the borders of intracellular bacterial infections and lymphoproliferative disorders (especially granulomatosis lymphomatoid of Liebow) [80]. The negativity of ANCAs and the lack of improvement during treatment should suggest the condition recently described in subjects with a genetic deficiency of TAP complex (transporter associated with antigen presentation) [81].

\section{Treatment}

Before the use of glucocorticoid therapy, GW was considered fatal within an average of 5 months, mainly due to end-stage renal failure before the advent of hemodialysis. These old statistical data do not account for the clinical polymorphism of the disease, with fluctuations in activity and sometimes prolonged spontaneous survival, especially in localized forms. The current treatment of GW has an overall satisfactory efficacy at the cost of a significant iatrogenesis, not only in terms of morbidity but also of mortality related to its administration duration. In addition, some of these complications (infections, allergies, renal failure, hematuria ...) are difficult to distinguish from a specific disease. Therapeutic innovation therefore aims above all to develop, in addition to new drugs with a more eradicative aim, administration techniques or even less toxic sequential schemes. Thus the distinction between treatment of attack and maintenance, if it seems a little artificial, has the merit of designating 2 essentially different therapeutic situations of purpose: the obtaining of a complete remission and the prevention of relapses.

\section{Iniatial treatment \\ Corticosteroids}

Conventional therapy involves the combination of prednisone at the initial dose of $1 \mathrm{mg} /$ $\mathrm{kg} / \mathrm{day}$ and a cytotoxic agent. Indeed, the use of corticoids alone in the treatment of stroke, especially in cases of diffuse disease with renal damage, does not allow to obtain a complete remission, the median survival being only 5 months (without corticosteroids) to 12 months [82]. The initial dose of prednisone is maintained for a duration of an average of 1 month [5, 44], which most often makes it possible to objectify a resolution of signs of activity. Fauci then calls the passage to an alternating corticosteroids [5], the total duration of the corticosteroid therapy is 12 months [5, 83 ], shorter than in other teams.

\section{Methotrexate}

The prednisone and methotrexate combination was proposed first line in 42 patients with histologically proven GW patients but not involving life-threatening speedily (creatinine less than $220 \mathrm{umol} / 1$, absence of acute hypoxemic intra-alveolar haemorrhage area...) [83]. In 15 cases, it was an inaugural push. Methotrexate was administered orally, initially at a dose of $0.3 \mathrm{mg} / \mathrm{kg} /$ week without exceeding $15 \mathrm{mg} /$ week for 1 to 2 weeks, and then gradually increased by weekly increments of $2.5 \mathrm{mg}$ to $20-25$. $\mathrm{mg} /$ week. Decreases in prednisone doses were based on the standard NIH protocol, with complete discontinuation occurring after an average of 7 months. Complete remission was obtained in $71 \%$ of the cases within an average of 4.2 months. Pneumocystosis of early onset was observed in 3 cases including 2 deaths in patients treated with methotrexate and high doses of corticosteroids. The authors suggest the systematic prophylactic use of cotrimoxazole (at a low dose of 3 tablets per week), which is theoretically contraindicated because of the expected bone marrow toxicity associated with these antifolicdrugs. Methotrexate may therefore be an alternative to the cyclophosphamide, either immediately in some limited forms of $\mathrm{GW}$, or secondarily after conventional short-term induction therapy in diffuse forms of the disease [84].

\section{Cotrimoxazole}

Cotrimoxazole was proposed in 1985 in monotherapy, mostly on empirical grounds, [85] as granulomatous initial treatment of subacute and localized Wegener. The use of this treatment, as a firstline treatment, has been the subject of controversy which remains valid, in the absence of a methodologically satisfactory assay [86]. A recent, prospective, open, non-randomized study was conducted in 19 patients with ENT-localized disease, without systemic vasculitis or significant impairment of general health state. The use of Cotrimoxazole alone, at 
a daily oral dose of 2 tablets of Bactrim forte $\AA$, resulted in 11 remissions (6 complete and 5 partial) with an average duration of 17 months (6-88 months). In 5 patients, locoregional progression was clear and in 3 other non-responders the disease was secondarily generalized within 24 to 60 months.In this study, the overall effectiveness was $58 \%$ [87]. The use of cotrimoxazole as a first-line treatment appears "reasonable" only in the rare forms localized to the upper airways, with no general signs [88].

Conversely, because of the high risk of potentially fatal pneumocysts [89-92], co-trimoxazole prophylaxis should be added to corticosteroid and immunosuppressive therapy during the attack phase. It is to say during the first year of treatment, and especially as there is a global lymphopenia (largely iatrogenic) sometimes deep. Pentamidine aerosols have also been proposed, particularly in patients treated with methotrexate [83].

\section{Maintenance Therapy}

The evolution of the GW is marked by a high rate of relapse, of the order of 30 to $50 \mathrm{p}$. [5], these relapses occurring at a variable distance from the first thrust, until 20 years after stopping any treatment. The increase in c-ANCA titers was initially considered a predictor of GW clinical outcome [93]. Some authors have even proposed to strengthen treatment on this single biological argument [94]. The NIH study, which covers the largest published series of Wegener's disease, has actually shown that ANCA titers are paralleling $64 \%$ clinical activity. In $100 \%$ of the cases, the ANCA elevation precedes the push in only $24 \%$ of the cases [9 5]. Conversely, in $36 \%$ of the cases, the clinical and biological evolutions were uncorrelated or even completely discordant. The increase in ANCA titers was re-evaluated: this is a relapse index with a sensitivity of $43 \%$ with a positive predictive value of $23 \%$, therefore quite weak [96].

This significant risk of relapse explains why immunosuppressive therapy is usually prescribed for at least 1 year after obtaining complete remission [83, 97]. Dose reduction is always gradual before complete cessation. To avoid the cumulative toxicity of cyclophosphamide, sequential alternative treatment regimens, first using oral cyclophosphamide for a limited period of time to achieve complete remission, followed by relay therapy with another drug (cotrimoxazole, methotrexate, azathioprine), are under evaluation.

In a double-blind, placebo-controlled study, cotrimoxazole (2 tablets of Bactrim forte daily for 2 years) significantly reduced relapse rate in patients in complete remission, whether they were treated in combination (approximately half of all cases) or not with prednisolone and / or cyclophosphamide. At 2 years old, $82 \%$ of patients treated with cotrimoxazole were still in remission compared to $60 \%$ of those treated with placebo. This significant reduction in the rate of relapse was a parallel to the decrease in the frequency of infections and unrelated to the evolution of the ANCA titer [98].

The use of methotrexate has also been proposed after obtaining complete or partial remission by conventional treatment. An open study compared four groups of patients receiving methotrexate intravenously or cotrimoxazothe, with or without corticosteroids [99]. The previous duration of treatment with oral cyclophosphamide was unfortunately very heterogeneous and variable depending on the groups. Methotrexate appeared to be more effective than cotrimoxazole in patients treated with or without corticosteroids $(91 \%$ vs. $0 \%$ and $86 \%$ vs. $58 \%$, respectively). However, the limitations of this openlabel study (small groups, short duration) reduce its scope [99].

\section{CONCLUSION}

Wegener is a rare granulomatosis in Africa. It is characterized by a clinical polymorphism. Its diagnosis is very difficult, leading to complications that can affect the functional and vital prognosis.

Management is multidisciplinary with early corticosteroid therapy and the use of other immunosuppressive therapy.

\section{REFERENCES}

1. Klinger H. Grenzformen der periarteritis Nodosa. Frankf Z Pathol. 1931, 42:455-480.

2. Wegener F. Ùber generalisierte, septische Efàberkrankungen. Verh Deutch Pathol Ges, 1936, 29: 202-210.

3. Godman GC, Churg J. Wegener's granulomatosis: pathology and review of the literature. Arch Pathol, 1954, 58: 533-553.

4. Carrington CB, Liebow AA. Limited forms of angiitis and granulomatosis of Wegener's type. Am J Med, 1966, 41: 497-527.

5. Fauci AS, Haynes BF, Katz P et coll. Wegener's granulomatosis: prospective clinical and therapeutic experience with 85 patients for 21 years. Ann Intern Med, 1983, 98: 76-85.

6. Cotch MF, Hoffman GS, Yerg DE et coll. The epidemiology of Wegener's granulomatosis: Estimates of the five-year period prevalence, annual mortality, and geographic disease distribution from population-based data sources. Arthritis Rheum. 1996, 39 : 87-92.

7. Anderson G, Coles ET, Crane M et coll. Wegener's granuloma A series of 265 British cases seen between 1975 and 1985 -A report by a subcommittee of the British Thoracic Society Research Committee. QJMed. 1992, 83: 427-438.

8. Andrews M, Edmunds M, Campbell An et coll. Systemic vasculitis in the 1980s: is there an 
increasing incidence of Wegener's granulomatosis and microscopic polyarteritis? J R Coll Physicians. 1990, 24: 284-288.

9. Carruthers DM, Watts RA, Symmons DPM ET coll. Wegener's granulomatosis-increased incidence or increased recognition? Br J Rheumatol. 1996, 35 : 142-145.

10. Falk RJ, Terrell RS, Charles LA et coll. Antineutrophil cytoplasmic autoantibodies induce neutrophils to degranulate and produce oxygen radicals in vitro. Proc Natl Acad Sci. 1990, 87: 4115-4119.

11. Raynauld J, Bloch DA, Fries JF. Seasonal variation in the onset of Wegener's granulomatosis, polyarteritis-nodosa and giant cell arteritis. J Rheumatol. 1993, 20: 1524-1526.

12. Devaney KO, Travis WD, Hoffman GS et coll. Interpretation of head and neck biopsies in Wegener's granulomatosis. A pathologic study of 126 biopsies in 70 patients. Am J Surg Pathol. 1990, 14: 555-564.

13. Fahey JL, Leonard E, Churg J et coll. Wegener's granulomatosis. Am J Med. 1954, 17: 168-179.

14. Walton EW. Giant cell granuloma of the respiratory tract (Wegener's granulomatosis). $\mathrm{Br}$ Med J. 1958, 2: 265-270.

15. Pinching AJ, Rees AJ, Pussell BA et coll. Relapses in Wegener's granulomatosis: the role of infection. Br Med J. 1980, 281: 836-838.

16. Lawyer C, Henkle J, Bakir H. Nasal carriage of staphylococcal infection in Wegener granulomatosis. Ann Intern Med. 1994, 121: 74-75.

17. Stegeman CA, Tervaert JWC, Sluiter WJ et coll. Association of chronic nasal carriage of Staphylococcus-aureus and higher relapse rates in Wegener's granulomatosis. Ann Intern Med, 1994, 120: $12-17$.

18. DE Remee RA, Mcdonald TJ, Harrison EG et coll. Wegener'. Granulomatosis. Anatomic correlates. A proposed classification. Mayo ClinProc, 1976, 5/: 777-781.

19. Stegeman CA, Tervaert JWC, Dejong PE et coll. Trimethoprim sulfamethoxazole (co-trimoxazole) for the prevention of relapses of Wegener's granulomatosis. N Engl J Med, 1996, 335: 16-20.

20. Flnkel TH, Tôrôk TJ, Ferguson PJ et coll. Chronic parvovirus B19 infection and systemic necrotising vasculitis: opportunistic infection or aetiological agent? Lancet. 1994, 343: 1255-1258.

21. Nikkari S, Mertsola J, Korvenranta $\mathrm{H}$ et coll. Wegener's granulomatosis and parvovirus B19 infection. Arthritis Rheum, 1994, 37: 1707-1708.

22. Nikkari S, Vainionpaâ R, Toivanen $\mathrm{P}$ et coll. Association of Wegener's granulomatosis with parvovirus B19 infection: in response. Arthritis Rheum. 1995, 38: 1175.

23. Katz P, Alling DW, Haynes BF et coll. Association of Wegener's granulomatosis with HLA-B8. Clin Immunol Immunopathol, 1974, 14: 268-270.
24. Cotch MF, Fauci AS, Hoffman GS. HLA typing in patients with Wegener granulomatosis. Ann Intern Med, 1995, 122: 635.

25. Zhang L, Jayne DRW, Zhao MH et coll. Distribution of MHC class II alleles in primary systemic vasculitis. Kidney Int, 1995, 47: 294-298.

26. Papiha SS, Murty GE, Ad'hia A et coll. Association of Wegener's granulomatosis with HLA antigens and other genetic markers. Ann Rheum Dis, 1992, 51: 246-248.

27. Elkon KB, Sutherland DC, Rees AJ et coll. HLA antigen frequencies in systemic vasculitis: increase in HLA-DR2 in Wegener's granulomatosis. Arthritis Rheum, 1983, 26: 102-105.

28. Cotch MF, Fauci AS, Hoffman GS. HLA typing in patients with Wegener granulomatosis. Ann Intern Med, 1995, 122: 635.

29. Hay EM, Beaman M, Ralston AJ et coll. Wegener's granulomatosis occurring

30. 152. Muniain MA, Moreno JC, Campora RG. Wegener's granulomatosis in two sisters. Ann Rheum Dis, 1986, 45: 417-421.

31. Sewell RF, Hamilton DV. Time-associated Wegener's granulomatosis in two members of a family. Neprol Dial Transplant, 1992, 7: 882.

32. Kallenberg CM, Mulder AHL, Cohen-Tervaert JW. Antineutrophil cytoplasmic antibodies: a stillgrowing class of autoantibodies in inflammatory disorders. Am J Med. 1992, 93: 675-682.

33. Kao JK, Weinberger M, Oddone EZ et coll. The role of antineutrophil cytoplasmic antibody (cANCA) testing in the diagnosis of Wegener graulomatosis. A literature analysis and metaanalysis. Ann Intern Med. 1995, 123: 925-932.

34. Kallenberg CGM, Brouwer E, Mulder AHL et coll. ANCApathophysiology revisited. Clin Exp Immunol, 1995, 100: 1-3.

35. Davies DJ, Moran JE, Niall JF et coll. Segmental necrotizing glomerulonephritis with antineutrophil antibody: possible arbovirus aetiology? Br Med J (Clin Res). 1982, 285: 606.

36. Van Der Woude FJ, Rasmussen N, Lobatto Set coll. Autoantibodies against neutrophils and monocytes: tools for diagnosis and marker for disease activity in Wegener's granulomatosis. Lancet. 1985, i: 425-429.

37. Rottem M, Fauci AS, Hallahan CW et coll. Wegener's granulomatosis in children and adolescents: clinical presentation and outcome. J Pediatr, 1993, 122: 26-31.

38. Luqmani RA, Bacon PA, Beaman $\mathrm{M}$ et coll. Classical versus nonrenal Wegener's granulomatosis. Q J Med, 1994, 87: 161-167.

39. Hoffman GS, Kerr GS, Leavitt RY et coll. Wegener's granulomatosis: an analysis of 158 patients. Ann Intern Med. 1992, 116: 488498.

40. Cordier JF, Valeyre D, Guillevin L et coll. Pulmonary Wegener's granulomatosis. A clinical and imaging study of 77 cases. Chest. 1990, 97:906-912. 
41. Justrabo E, Plard F, Michields JF et coll. Évolution favorable de la maladie de Wegener limitée aux poumons. Rev Mal Respir Dis, 1990, 7: 69-72.

42. LE Thi Huong D, Wechsler B, Chamuzeau JP et coll. Pulmonary aspergilloma complicating Wegener's granulomatosis. Scand J Rheumatol. 1995, 24: 260.

43. Brandwein S, Esdaile J, Danoff D et coll. Wegener's granulomatosis. Clinical features and outcome in 13 patients. Arch Intern Med. 1983, 143: 476-479.

44. Haworth SJ, Savage COS, CARR D et coll. Pulmonary haemorrhage complicating Wegener's granulomatosis and microscopic polyarteritis. $\mathrm{Br}$ Med J. 1985, 290: 1775-1778.

45. Hensley MJ, Feldman NT, Lazarus JM, Galvanek EG. Diffuse pulmonary hemorrhage and rapidly progressive renal failure: An uncommon presentation of Wegener's granulomatosis. The American journal of medicine. 1979 May 1;66(5):894-8.

46. Sauvaget F, LE THI HD, Piette JC, Wechsler B, Blétry O. Hémorragies intra-alvéolaires de la granulomatose de Wegener: étude rétrospective de 9 cas. La Presse médicale (1983). 1993;22(15):70911.

47. Thomas D, Moore R, Donovan K, Wheeler D, ESNAULT VM. Pulmonary-renal syndrome in asssociation with anti-GBM and IgM ANCA. Lancet (British edition). 1992;339(8804).

48. Barksdale SK, Hallahan CW, Kerr GS, Fauci AS, Stern JB, Travis WD. Cutaneous pathology in Wegener's granulomatosis. The American journal of surgical pathology. 1995 Feb 1;19(2):161-72.

49. Daoud MS, Gibson LE, DE Remef. RA et coll. Cutaneous Wegener's granulomatosis: climcaLhistopathologic, and immunopathologic features of thirty patients. J Am Acad Dermatol, 1994, 31: 605-612.

50. Francès C, Piette JC, Saada V, Boisnic S, Wechsler $\mathrm{B}$, Blétry O, Godeau P. Wegener's granulomatosis: dermatological manifestations in 75 cases with clinicopathologic correlation. Archives of dermatology. 1994 Jul 1;130(7):861-7.

51. Hu CH, O'Loughlin S, Winkelmann RK. Cutaneous manifestations of Wegener granulomatosis. Archives of Dermatology. 1977 Feb 1;113(2):17582.

52. Jayne DR, Esnault VL, Lockwood CM. ANCA anti-idiotype antibodies and the treatment of systemic vasculitis with intravenous immunoglobulin. Journal of autoimmunity. 1993 Apr 1;6(2):207-19.

53. Patten, S. F., \& Tomecki, K. J. (1993). Wegener's granulomatosis: cutaneous and oral mucosal disease. Journal of the American Academy of Dermatology, 28(5), 710-718.

54. Pinching AJ, Lockwood CM, Pussell BA, Rees AJ, Sweny P, Evans DJ, Bowley N, Peters DK. Wegener's granulomatosis: observations on 18 patients with severe renal disease. QJM: An International Journal of Medicine. 1983 Oct 1;52(4):435-60.

55. Daoud MS, Gibson LE, Dahl PR, Muller SA Cutaneous Wegener's granulomatosis presenting as pyoderma gangrenosum-like ulceration. EJD. European journal of dermatology. 1995;5(1):23-7.

56. Tullo AB, Durrington P, Graham E, Holt LP, Easty DL, Bonshek R, Noble JL. Florid xanthelasmata (yellow lids) in orbital Wegener's granulomatosis. British journal of ophthalmology. 1995 May $1 ; 79(5): 453-6$.

57. Kavanagh GM, Colaco CB, Bradfield JW, Archer CB. Erythema elevatum diutinum associated with Wegener's granulomatosis and $\operatorname{IgA}$ paraproteinemia. Journal of the American Academy of Dermatology. 1993 May 1;28(5):8469.

58. Jacobs RP, Moore M, Brower A. Wegener's granulomatosis presenting with erosive arthritis. Arthritis \& Rheumatism: Official Journal of the American College of Rheumatology. 1987 Aug;30(8):943-6.

59. OTHMANI, S., BAHRI, M., LOUZIR, B., ZIDI, B., \& M'SADDEK, F. (1991). Les manifestations articulaires au cours de la granulomatose de Wegener. La Semaine des hôpitaux de Paris, 67(37), 1679-1682.

60. Shuhart DT, Torretti DJ, Maksimak JF, George S. Acute myositis as an unusual presentation of Wegener's granulomatosis. Archives of pediatrics \& adolescent medicine. 1994 Aug 1;148(8):875-6.

61. NISHINO H, DeREMEE RA, RUBINO FA, Parisi JE. Wegener's granulomatosis associated with vasculitis of the temporal artery: report of five cases. InMayo Clinic Proceedings 1993 Feb 1 (Vol. 68, No. 2, pp. 115-121). Elsevier.

62. Small P, Brisson ML. Wegener's granulomatosis presenting as temporal arteritis. Arthritis \& Rheumatism: Official Journal of the American College of Rheumatology. 1991 Feb;34(2):220-3.

63. CHAKRAVARTY K, SCOTT DI, Blyth J, Courteney-Harris RG. Wegener's granulomatosis in the elderly-unusual presentations and misdiagnosis. Journal of rheumatology. 1994;21(6):1157-9.

64. Le Thi Huong D, Wechsler B, Cabane J et coll. Granulomatose de Wegener. Aspects cliniques, problèmes nosologiques. Revue de la littérature à propos de 30 observations. Ann Med Interne. 1988, 139 : 169-182.

65. Yousem SA, Lombard CM. The eosinophilic variant of Wegener's granulomatosis. Hum Pathol. 1988, $19: 682-688$.

66. Cuadrado MJ, D'cruz D, Llyod M et coll. Allergic disorders m systemic vasculitis. A case-controlled study. Br J Rheumatol. 1994, 55: 749-753.

67. Ronco P, Verroust P, Mignon F et coll. Immunopathological studies of polyarteritis nodosa and Wegener's granulomatosis: a report of 43 
patients with renal biopsies. Q J Med.1983, 206 : 212-223.

68. Grau GE, Roux-Lombard P, Gysler C et coll. Serum cytokine changes in systemic vasculitis. Immunology. 1989, 68 : 196-198.

69. Schmitt WH, Heesen C, Csernok E et coll. Elevated serum levels of soluble interleukin-2 receptor in patients with Wegener's granulomatosis - association with disease activity. Arthritis Rheum. 1992, 35: 1088-1096.

70. Ohdama S, Matsubara O, Aoki N. Plasma thrombomodulin in Wegener's granulomatosis as an indicator of vascular injuries. Chest. 1994, 106: 666-671.

71. Nassonov E, Samsonov M, Beketova $\mathrm{T}$ et coll. Serum neopterin concentrations in Wegener's granulomatosis correlate with vasculitis activity. Clin Exp Rheumatol. 1995, $13: 353-356$.

72. LEAVITT RY, FAUCI AS, BLOCH DA et coll. The American College of Rheumatology 1990 criteria for the classification of Wegener's granulomatosis. Arthritis Rheum, 1990, 33: 11011107.

73. Jennette JC, Falk RJ, Andrassy $\mathrm{K}$ et coll. Nomenclature of systemic vasculitides. Proposal of an International Consensus Conference. Arthritis Rheum. 1994, 37: 187-192.

74. Rao JK, Weinberger M, Oddone EZ et coll. The role of antineutrophil cytoplasmic antibody (cANCA) testing in the diagnosis of Wegener granulomatosis. A literature review and metaanalysis. Ann Intern Med. 1995, 123: 925-932.

75. Sauvaget F, LE Thi Huong D, Piette JC et coll. Hémorragies intra-alvéolaires de la granulomatose de Wegener. Presse Méd. 1993, 22 : 709-711.

76. Rao JK, Allen NB, Feussner JR et coll. A prospective study of antineutrophil cytoplasmic antibody (c-ANCA) and clinical criteria in diagnosing Wegener's granulomatosis. Lancet. 1995, 346: 926-931.

77. Pudifin DJ, Duursma J, Gathiram V et coll. Invasive amoebiasis is associated with the development of anti-neutrophil cytoplasmic antibody. Clin Exp Immunol. 1994, 97: 48-51.

78. Papo T, Piette JC, Godeau P. Les anticorps anticytoplasme des polynucléaires neutrophiles sont-ils pathogènes?. La Revue de médecine interne. 1994 Jan 1;15(2):110-5.

79. Papo T, Piette JC, Laraki R, Bletry O, Huong DL, Godeau P. Silent myocardial infarction in Wegener's granulomatosis. Annals of the rheumatic diseases. 1995 Mar;54(3):233.

80. Meryhew NL, Bache RJ, Messner RP. Wegener s granulomatosis with acute pericardial tamponade. Arthritis \& Rheumatism: Official Journal of the American College of Rheumatology. 1988 Feb;31(2):300-2.

81. HOLLANDER D, MANNING RT. The use of alkylating agents in the treatment of Wegener's granulomatosis. Annals of Internal Medicine. 1967 Aug 1;67(2):393-8.

82. Sneller MC, Hoffman GS, Talar- Williams C, Kerr GS, Hallahan CW, Fauci AS. An analysis of fortytwo Wegener's granulomatosis patients treated with methotrexate and prednisone. Arthritis \& Rheumatism: Official Journal of the American College of Rheumatology. 1995 May;38(5):608-13.

83. Stavrou P, Deutsch J, Rene C, Laws DE, Luqmani RA, Murray PI. Ocular manifestations of classical and limited Wegener's granulomatosis. QJM: An International Journal of Medicine. 1993 Nov 1;86(11):719-25.

84. DeREMEE RA, McDONALD TJ, WEILAND LH. Wegener's granulomatosis: observations on treatment with antimicrobial agents. InMayo Clinic Proceedings 1985 Jan 1 (Vol. 60, No. 1, pp. 27-32). Elsevier.

85. Deremee RA. The treatment of Wegener's granulomatosis with trimethoprim/sulfamethoxazole: illusion or vision? Arthritis \& Rheumatism: Official Journal of the American College of Rheumatology. 1988 Aug;31(8):1068-72.

86. Reinhold-Keller E, De Groot K, Rudert H, Nölle B, Heller M, Gross WL. Response to trimethoprim/sulfamethoxazole in Wegener's granulomatosis depends on the phase of disease. QJM: monthly journal of the Association of Physicians. 1996 Jan 1;89(1):15-23.

87. Wechsler, B., De Gennes, C., Raguin, G., Piette, J. C., Bletry, O., \& Godeau, P. (1990). Traitement par le cotrimoxazole de la granulomatose de Wegener (7 observations). La Revue de médecine interne, 11(1), 87-89.

88. Godeau B, Mainardi JL, Roudot-Thoraval F, Hachulla E, Guillevin L, Du LH, Jarrousse B, Remy P, Schaeffer A, Piette JC. Factors associated with Pneumocystis carinii pneumonia in Wegener's granulomatosis. Annals of the rheumatic diseases. 1995 Dec 1;54(12):991-4.

89. Jarrousse B, Guillevin L, Bindi P, Hachulla E, Leclerc P, Gilson B, Remy P, Rossert J, Jacquot C, Nilson B. Increased risk of Pneumocystis carinii pneumonia in patients with Wegener's granulomatosis. Clinical and experimental rheumatology. 1993;11(6):615.

90. Ognibene FP, Shelhamer JH, Hoffman GS, Kerr GS, Reda D, Fauci AS, Leavitt RY. Pneumocystis carinii pneumonia: a major complication of immunosuppressive therapy in patients with Wegener's granulomatosis. American journal of respiratory and critical care medicine. 1995 Mar;151(3):795-9.

91. Walton, E. W. (1958). Giant-cell granuloma of the respiratory tract (Wegener's granulomatosis). British medical journal, 2(5091), 265.

92. Tervaert JW, van der Woude FJ, Fauci AS, Ambrus JL, Velosa J, Keane WF, Meijer S, van der Giessen 
M, van der Hem GK, Kallenberg CG. Association between active Wegener's granulomatosis and anticytoplasmic antibodies. Archives of internal medicine. 1989 Nov 1;149(11):2461-5.

93. Kerr GS, Fleisher TA, Hallahan CW, Leavitt RY, Fauci AS, Hoffman GS. Limited prognostic value of changes in antineutrophil cytoplasmic antibody titer in patients with Wegener's granulomatosis. Arthritis \& Rheumatism: Official Journal of the American College of Rheumatology. 1993 Mar;36(3):365-71.

94. Davenport A, Lock RJ, Wallington T. Clinical significance of the serial measurement of autoantibodies to neutrophil cytoplasm using a standard indirect immunofluorescence test. American journal of nephrology. 1995;15(3):201-7.
95. Haubitz M, Frei U, Rother U, Brunkhorst R, Koch KM. Cyclophosphamide pulse therapy in Wegener's granulomatosis. Nephrology Dialysis Transplantation. 1991 Jan 1;6(8):531-5.

96. Stegeman CA, Cohen Tervaert JW, de Jong PE, Kallenberg CG. Trimethoprim-sulfamethoxazole (co-trimoxazole) for the prevention of relapses of Wegener's granulomatosis. New England Journal of Medicine. 1996 Jul 4;335(1):16-20.

97. de Groot K, Reinhold- Keller E, Tatsis E, Paulsen J, Heller M, Nölle B, Gross WL. Therapy for the maintenance of remission in sixty- five patients with generalized Wegener's granulomatosis. Methotrexate versus trimethoprim/sulfamethoxazole. Arthritis \& Rheumatism. 1996 Dec;39(12):2052-61. 